International Journal of Linguistics, Literature and Translation

ISSN: 2617-0299 (Online); ISSN: 2708-0099 (Print)

DOI: 10.32996/ijltt

Journal Homepage: www.al-kindipublisher.com/index.php/ijllt

\title{
Active Subtitling as a Learning Tool for ESP Students
}

\author{
Dr. Abdelouahab Elbakri 8(D) \\ University of Ibn Zohr, Agadir, Morocco
}

$\triangle$ Corresponding Author: Dr. Abdelouahab Elbakri, E-mail: abdelouahabelbakri@gmail.com

\section{ARTICLE INFORMATION}

Received: July 05, 2021

Accepted: August 19, 2021

Volume: 4

Issue: 8

DOI: $10.32996 / i j l l t .2021 .4 .8 .19$

\section{KEYWORDS}

Subtitling, ESP, active, authentic videos, vocabulary
ABSTRACT

This article aims at approaching subtitling as a tool for English for Specific Purposes (ESP) students. It provides a description of the important role audiovisual translation (AVT) plays in language teaching/learning. It is based on scholars' work, including (Sokoli 2006; Diaz Cintas 2013; Talavan 2007). This paper tackles the pedagogical application of subtitling in an ESP context as it enhances individual and collaborative learning, exposure to and interaction with real and new complex situations, and developing different linguistic skills. The article presents a classification of the different types of subtitles that are used in language teaching/learning and considers the pros of using subtitled videos as a didactic tool to enhance vocabulary learning for ESP students. Accordingly, the paper emphasises active subtitling, a technique in which learners create their own subtitles, especially with the groundbreaking progress of IT technology (Diaz Cintas 2012; Talavan 2013). The article ends by presenting the findings of an experiment I have conducted in my engineering classes on the basis of active subtitles.

\section{Introduction}

Audiovisual media are appealing because they are a ludic way of communication. We can communicate complex messages using a composite of acoustic and visual channels and the outcome is just breathtaking. Every single second, millions of octets of information are diffused in the vast space of artificial intelligence and they are received, consumed and shared on the spot. The effect is even more magnificent among young generations. A tremendous situation like this is an incredibly fertile ground for the blossoming of audiovisual technology in the field of learning/teaching. Using technology in teaching has grown exponentially. The omnipresence of the internet in the lives of people and the change of the role of the teacher from an absolute holder of knowledge to a mediator and facilitator has made the use of technology unavoidable.

It is inconceivable that teachers would not take advantage of this enormous opportunity to motivate learners and boost their potential. Audiovisual translation is one of the pedagogical tools that have gained considerable ground lately in language teaching. Subtitling, in particular, has gained impetus in the discipline and an important number of teachers are resorting to it to enhance their students' language skills and strengthen their lexical development.

This paper aims at highlighting the educational potential of subtitling in language learning for ESP students. It attempts to underpin the crucial role that this pedagogical tool can play in language acquisition in general and vocabulary learning in particular.

\section{The theoretical framework}

\subsection{The use of translation in language teaching}

For many years, translation was considered a basic tool for language learning with the supremacy of the grammar-translation method, which dominated Europe for over a century. It aimed to enhance the students' ability to read materials written in a foreign language (L2) by translating its content into their native language (L1). The method was elaborated during the nineteenth century and became the dominant approach to teaching foreign languages in European schools from the 1840 s to

K C AL-KINDI CENTER

$\mathbf{R}$ D FOR RESEARCH AND DEVELOPMENT

Your gateway to world-class research

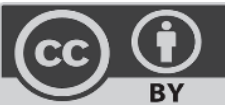

Published by Al-Kindi Center for Research and Development, London, United Kingdom. Copyright (c) the author(s). This open access article is distributed under a Creative Commons Attribution (CC-BY) 4.0 license 
the 1940s. It was progressively discarded from the teaching and learning of foreign languages as it was believed that the use of the mother tongue in class would impede the students' learning and fluency. Then, new educational approaches swept their way into the classroom, inter alia, the communicative approach that favoured the foreign language's sole use. It was considered to be the only option available to master communicative fluency, and translation had no place in this setting (Cummings 2007: 223). The communicative approach aimed at enabling the learner to communicate in L2 through using authentic materials, promoting listening comprehension activities, motivating students to interact in class, and devising activities that have real communicative potential (objectives that translation has later proved to achieve, especially with audiovisual translation.)

With the establishment of translation studies as a scholarly discipline, the use of translation in language learning has taken a different turn. The arguments against the benefits of translation activities in L2 classrooms have increasingly been refuted. Widdowson (2003: 160) claims that "translation has been too long in exile, for all kinds of reasons which [...] have little to do with any considered pedagogic principle. It is time it was given a fair and informed appraisal". Hatim and Mason (1997) argue that its role has been reconsidered due to the emphasis given to its value as a communicative activity of mediation. Hurtado (1999) contends that it assists in the development of reading comprehension and written expression, the promotion of linguistic knowledge and the development of cultural competence. Cook (2010 cited in Noa Talaván and Pilar Rodríguez-Arancón 2015: 275) claims that learning and using translation "demands knowledge and understanding of both languages and of the relationships between them." For the last couple of decades now, translation has started to gain more impetus within the language learning context.

With the advent of the digital era, audiovisual translation (AVT) has become an important tool used to enhance learning either in the classroom or independently. Amazingly enough, it is considered today one of the most efficient techniques used to boost students' learning and motivation to learn.

\subsection{AVT and subtitling}

Chaume (2013: 107) defines AVT as "a mode of translation characterized by the transfer of audiovisual texts either interlingually or intralingually." Within this process, two channels of communication are used simultaneously. The 'audio/acoustic' channel provides words, paralinguistic information, soundtrack and special effects; while the 'visual' channel transmits images, colors, movement, posters or captions with linguistic signs.

AVT modes comprise all types of transfer of audiovisual texts between two languages and cultures (interlingual) or within the same language and culture (intralingual). Chaume argues that "audiovisual texts are made by introducing on-screen ... a (written) target text ...translation... or by inserting a new soundtrack in a different language" (ibid.). In other words, AVT covers all sorts of semiotic transfers, namely dubbing, subtitling, fansubbing, fandubbing, surtitling, respeaking, audiosubtitling, voice-over and audiodescription. In the context of this paper, our concern is subtitling.

Diaz Cintas (2013) describes subtitling as "a translation practice that consists of rendering in writing, usually at the bottom of the screen, the translation into a target language (or even into the same source language) of the original dialogue exchanges uttered by different speakers, as well as other verbal information that appears written on-screen (letters, banners, inserts) or is transmitted aurally in the soundtrack (song lyrics, voices off)" (274).

According to Cintas Diaz, subtitling involves some key notions. It is primordially an inter-lingual process that doesn't exclude both intra-lingual subtitling and the subtitling for the deaf and hard of hearing. Moreover, it goes beyond the spoken to include the displayed (the written signs) and the captioned (the superimposed titles) language. He also stresses that the notion of 'line' may be read from left to right (as in English) or from right to left (as in Arabic). These lines have to be displayed in synchrony with the utterance of the text on the screen.

Diaz Cintas (2010) identifies three types of subtitling: bimodal subtitles (intra-lingual, subtitles and soundtrack in the same language); standard subtitles (inter-lingual, mother tongue subtitles and foreign language soundtrack); reversed subtitles (interlingual, foreign language subtitle and mother tongue soundtrack).

\subsection{The use of video materials in teaching languages}

Videos can be used as a tool to initiate or improve the process of acquiring a foreign language. They can also be utterly useful in complementing the traditional textbooks and curricula (our approach in this paper). They allow students to witness how native speakers of another language communicate and interact in real contexts as they are closer to real-life and provide visual clues and contexts that make it possible to "view" the message as much as listen to it (Baltova 1994: 508). Videos offer both linguistic communicative cues such as accents and intonation as well as paralinguistic cues such as gestures and body movements (Jorge Díaz Cintas and Marco Fernández Cruz 2006: 202). 
Videos can thus be an extremely effective way to enhance students' input in accordance with Krashen's theory of second language acquisition, who argues that we acquire language "by understanding messages or by receiving comprehensible input" (Krashen 1985: 2). Videos can provide students with good "comprehensible input" as linguistic meaning is conveyed through extralinguistic cues such as images, actions, etc. The acquisition of this input varies from one learner to another depending on what Krashen (1987) names as 'the affective filter'; in other words, they are the various affective factors that can positively or negatively influence the development of auditory comprehensions, such as the level of anxiety, motivation or self-esteem that a specific task can have in the student(Díaz Cintas and Fernández Cruz 2006: 204). It is commonly argued that the use of videos in the classroom boosts the students' motivational level (low affective filter).

For the last three decades, numerous experiments were conducted to gauge the effect of using videos in language learning classrooms. Heron and Hanley (1992) conclude that the extensive use of video improves the students' listening comprehension skills. Heron et al. (1995) posit that there is a direct developmental relationship among the various learning skills, i.e. speaking, reading, grammar learning, writing, and listening. Any development of a particular skill may affect others. Mayer (2009) coins the term "multimedia effect" to explain the use of a combination of visual and aural information in order to affect learning which includes all learning skills (without exception). These studies, among others, conclude that videos are extremely functional tools to enhance language learning in classrooms and their benefit falls on all learning skills.

However, practically speaking, videos are effective pedagogical tools only when used appropriately within the classroom context. Both teachers and learners have to perform their roles efficiently. A task-based viewing is more likely to achieve its objectives than passive viewing. So, teachers need to assign tasks and design worksheets for students to use while watching; and students need to participate actively by solving their tasks and giving feedback. Learning, thus, becomes more enjoyable and more effective and students learn enormous quantities of material and perform complicated tasks rapidly and confidently. (Robinson 1997:3)

\subsection{The use of subtitling in language teaching}

Talavan (2013) argues that the pedagogical applications of AVT to the L2 educational framework are very recent. It is undeniable that performing a task while watching or listening to an AVT text is a quite old practice. However, the active use of AVT for language learning is just as old as the advent of ICT. Therefore, academic research on the subject is even more recent and quite limited. In relation to our field of concern in this article, namely subtitling, an important number of articles, books and journals have been written, attempting to exploit its educational aspects during the last two decades. These researches have investigated topics such as: software development (Sokoli et al. 2011; Navarrete 2013), vocabulary acquisition (Lertola 2012), intercultural awareness (Borghetti 2011), didactics (Cintas Diaz 2012), listening comprehension (Talaván 2011; Williams and Thorne 2000), integrated skills (Incalcaterra and Lertola 2014), writing skills (Talaván and Rodríguez-Arancón 2014), teacher training (López Cirugeda and Sánchez-Ruiz 2013), English for specific purposes (Buil-Beltrán, Paula 2018) (cited in Talavan and RodríguezArancón 2015: 276)

These studies have concluded that the pedagogical application of AVT in general and subtitling, in particular has multifarious advantages. By performing a subtitling task, students can become more conscious of the differences between L1 and L2. "One way to make a foreign language feature noticeable or salient in the input is to enhance it by providing the contrastive association with the corresponding L1 item" (Laufer and Girsai 2008: 697). Another benefit is that these texts provide simultaneous exposure to spoken language, printed text, and visual information, conveying the same message (Baltova 1999: 33). They also promote content and vocabulary learning even in relatively inexperienced learners (ibid.). They may as well bridge the gap between reading, listening and all other skills.

More accurate studies have tried to classify the pedagogical applications of subtitling in accordance with its three types: bimodal, standard and reversed. Bimodal subtitles have been studied in relation to foreign language aspects such as listening comprehension (Huang and Eskey 1999), implicit and explicit aspects of vocabulary learning (Bird and Williams 2002) and listening and speaking for intermediate and advanced learners (Araújo 2008). Standard subtitles have been investigated to improve linguistic balance in non-equivalent bilinguals (De Bot et al. 1986), to encourage vocabulary acquisition thanks to mediation (Pavakanun and d"Ydewalle 1992), to develop learner motivation (Ryan 1998), to promote lexical acquisition in children (Koolstra and Beentjes 1999), and to enhance listening and speaking in beginners (Araújo 2008). Reversed subtitles have been researched to improve second language skills in general (Lambert et al., 1981); comprehension in general (Holobow et al., 1984); vocabulary acquisition in general (d"Ydewalle and Pavakanun, 1997) (cited in Talavan 2010: 287-288) These studies have concluded that the three types of subtitling are practical and useful to vocabulary acquisition. In other words, they can be successfully applied in the context of the classroom.

\subsection{The technical aspect of subtitling}

Subtitling is utterly exciting for students as it is based on technology. The widespread access to the internet and to 
technological devices (phones, tablets, computers...) has made the use of these devices in the process of teaching/learning absolutely unavoidable. The advent of digital technology has opened unforeseen potential for the development of specific subtitling softwares with new functionalities. Subtitling software programs were first used in the 1970's, but their application was too sophisticated and time-consuming and they were rather expensive and out of reach for many professional translators, let alone amateurs. Nowadays, the situation has changed quite drastically. "With a PC, a digital copy of the video, and a subtitling program, subtitlers can perform all pertinent tasks in front of a single screen: to create the timecodes, to respect shot changes, to control the reading speed of their subtitles, to translate and spell check their texts, to simulate their subtitles on screen, etc." (Diaz Cintas 2013: 124)

Today, professionals and even amateurs can easily download free subtitling software programs from the internet. There are also free online programs that are quite easy to use with assistance and guidance from professionals. The simplicity and easiness of these programs are very striking. They are very efficient in creating, adjusting, synchronizing, and translating subtitle lines. Hereinafter is a subtitling program interface that exemplifies these practical characteristics.

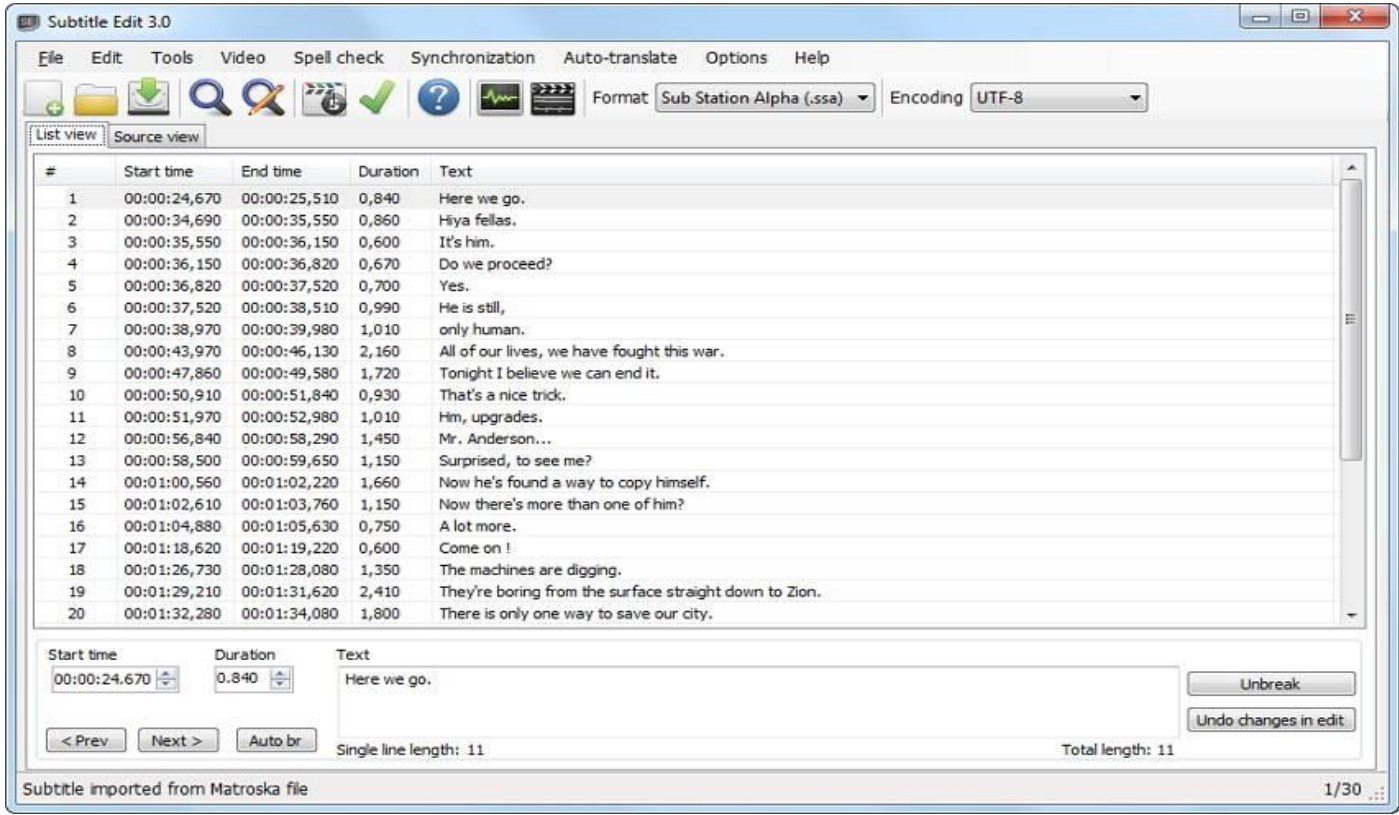

Interface of the subtitling program subtitle edit

It is crystal clear, from the above interface, that subtitling is no more a hard task; and here is a list of the most commonly used amateur subtitling programs.

1. Subtitle Edit : www.nikse.dk/subtitleedit

2. VisualSubSync : www.visualsubsync.org

3. Subtitle Workshop : www.subworkshop.sourceforge.net

4. SubtitleCreator : www.sourceforge.net/projects/subtitlecreator/

5. Aegisub Advanced Subtitle Editor : www.aegisub.org/downloads/

6. DivXLand Media Subtitler : www.divxland.org/en/media-subtitler/

7. WinSubMux : www.videohelp.com/software/WinSubMux

8. Subtitle Editor: www.videohelp.com/software/Subtitle-Edit

9. AHD Subtitles Maker: www.sourceforge.net/projects/ahdsubtitles/

10. SubEdit Player: www.subedit-player.informer.com

Any amateur user, including students, can use these programs individually or within translation workshops without any assistance. They are really light and effective, and their graphical interfaces are completely understandable and enjoyable.

\section{The pedagogical application}

Classroom subtitling can be carried out in a multitude of ways. The choice of the activity largely depends on the objective to meet and the skill to develop. It is also important to select the right type of subtitling and the appropriate video clip which can lead to the achievement of these objectives. 
In order to understand the potential usefulness of the pedagogical applications of subtitling and subtitles in language learning, a series of aspects needs to be defined: (1) software used, (2) subtitling mode, (3) type of subtitles, (4) video clip features, and (5) type of learning tasks. It should be noted that these parameters may vary according to the precise interests, resources and/or goals of the educational context in question.(Talavan 2010: 289)

In English for Specific Purposes (ESP), all types of subtitling are applicable. Dudley-Evans and St. Johns (1998) identify some of the aspects of ESP as follows: it is designed to meet specific needs of the learners, and it is centered on the language appropriate to these activities in terms of grammar, lexis, register, study skills, discourse and genre (cited in Buil-Beltrán 2018: 401). I have chosen vocabulary as an example due to its importance in the context of ESP. Effective ESP vocabulary teaching is the milestone in successfully implementing ESP programs. For students, it is a hard long-term process on which they spend a lot of time attempting to increase their lexicon through memorizing words and collocations included in the four skills. Subtitling has proved to be highly effective and enjoyable in vocabulary learning as words are directly associated with appropriate nonverbal referents (objects, events, emotions, context, etc.) "This overloading of information provided by the triple connection of image, sound and text plus the optional element of translation is very positive in terms of vocabulary learning" (Talavan 2007: 5).

In this study, I shall provide some samples of lesson activities using subtitling as support. As a teacher of English for engineering in "l'école polytechnique privée d'Agadir", I usually resort to these activities to endorse the textbook which sometimes falls into monotony and discourages students from staying motivated during each class. However, before putting the students on the rails of subtitling, they have to be initiated to the constrained nature of subtitling.

\subsection{Preparing students}

Titford (1982) introduced the term 'constrained translation' with regard to spatial and temporal constraints that evidently do not apply to most other forms of translation. Subtitlers should abide by some guidelines while performing their task. These rules include, in space terms, the number of lines, the position of titles on the screen and the segmentation of the text, and in temporal terms, the reading time and speed of the subtitles. Here are the most basic subtitling constraints:

- Subtitling has to be shorter than the original dialogues in the soundtrack.

- They usually occur in the middle of the screen.

- $\quad$ Each subtitle should be semantically and syntactically independent.

- It should not exceed two lines. The two-line standard enables to represent most of the verbal information and to keep the image clear of any disturbance.

- A subtitle should appear when a person starts speaking.

- The length of the segment equals the amount of time that the frame appears on screen (1/24 or $1 / 25$ seconds depending on the number of frames per second used).

- No single line or two-line subtitle should display on screen for more than six seconds.

- The subtitle must appear in the frame corresponding to that sound segment in which a person starts speaking.

Bearing these constraints in mind, students are then introduced to the subtitling software program that they are supposed to work with. As we have mentioned earlier, these software programs today are simple to handle and enjoyable to use. Both introductions (constraints and software) do not usually take more than two hours (a single class time) to recognize and master. Preferably, teachers should design a demonstration subtitling before the students start it by themselves.

\subsection{Activity procedure}

The objective of the activities is to endorse subtitling as a powerful pedagogical tool for vocabulary learning. I apply these techniques with third-year engineer students from 'l'école polytechnique privée d'Agadir' (which is a school for engineering within Universiapolis in Agadir). Students are usually required to create standard or reversed subtitling texts using French as L1 and English as L2 or perform vocabulary tasks relying on bimodal subtitles. The video clips are authentic videos which are related to one of the themes of the programmed textbook "Cambridge English for Engineering". The choice of the video clips is made on the basis of authenticity which offers students a better understanding of vocabulary items through constant oral reference to the images. The video clips do not usually exceed seven minutes. 
Here are two outlines exemplifying the use of these techniques

\section{Bimodal subtitles}

\begin{tabular}{|l|l|}
\hline \multicolumn{1}{|c|}{ Steps } & \multicolumn{1}{c|}{ Activities } \\
\hline $\begin{array}{l}\text { Pre-viewing } \\
5 \text { minutes }\end{array}$ & $\begin{array}{l}\text { Review/remind vocabulary previously learnt in textbook and purpose of } \\
\text { activity }\end{array}$ \\
\hline $\begin{array}{l}\text { First Viewing } \\
5 \text { to } 7 \text { minutes }\end{array}$ & First viewing of the video clip without any subtitles \\
\hline $\begin{array}{l}\text { Second viewing } 5 \\
\text { to } 7 \text { minutes }\end{array}$ & $\begin{array}{l}\text { Second viewing with standard subtitles, preferably with key vocabulary } \\
\text { items highlighted }\end{array}$ \\
\hline $\begin{array}{l}\text { Goal task } \\
10 \text { minutes }\end{array}$ & Fill in the gap activity or c-test vocabulary activity \\
\hline $\begin{array}{l}\text { Third viewing } \\
10 \text { minutes }\end{array}$ & Vocabulary checking and feedback \\
\hline
\end{tabular}

This activity can be used as a preparation for an advanced activity that includes either standard or reversed subtitling. The focus is $100 \%$ on vocabulary items as the script is given to students and they are asked to find the missing words (technical jargon related to the specific purpose). The easiness or difficulty of the activity depends entirely on the nature and degree of complexity of the video clip itself.

\section{Standard or reversed subtitles}

\begin{tabular}{|l|l|}
\hline \multicolumn{1}{|c|}{ Steps } & \multicolumn{1}{c|}{ Activities } \\
\hline $\begin{array}{l}\text { Pre-viewing } \\
5 \text { minutes }\end{array}$ & $\begin{array}{l}\text { Review/remind vocabulary previously learnt in textbook and purpose of } \\
\text { activity }\end{array}$ \\
\hline $\begin{array}{l}\text { First Viewing } \\
5 \text { to } 7 \text { minutes }\end{array}$ & First viewing of the video clip without any subtitles \\
\hline $\begin{array}{l}\text { Second viewing } 5 \\
\text { to } 7 \text { minutes }\end{array}$ & $\begin{array}{l}\text { Second viewing with bimodal subtitles, preferably with key vocabulary items } \\
\text { highlighted }\end{array}$ \\
\hline $\begin{array}{l}\text { Goal task } \\
20 \text { minutes }\end{array}$ & $\begin{array}{l}\text { Subtitling the clip from L2 to L1/standard subtitles or L1 to L2/ reversed } \\
\text { subtitles } \\
\text { (Pair or group work) }\end{array}$ \\
\hline $\begin{array}{l}\text { Third viewing } \\
20 \text { minutes }\end{array}$ & $\begin{array}{l}\text { One of the works is chosen randomly to display and discuss. Emphasis is put } \\
\text { on justifying vocabulary choice. }\end{array}$ \\
\hline
\end{tabular}

This activity is for advanced learning. The lesson is divided into three basic stages:

1. The preparation stage which includes the three first steps. First, the students brainstorm or build a semantic map of the vocabulary previously studied in the relative unit of the textbook. Then they view the authentic video clip (either in L1 or L2) which covers these vocabulary items without any subtitles followed by a second viewing with bimodal subtitles.

2. The task stage in which students proceed to the subtitling activity. The process is performed preferably as a group workshop to enhance collective learning which is extremely helpful in vocabulary acquisition.

3. The final stage is a remedial stage in which the teacher and students discuss the work of a group. It can also be used as a remedial stage for any misconception or misunderstanding of vocabulary items.

At the end of each year, a questionnaire is submitted to students to assess their learning and their satisfaction vis-a-vis the use of subtitling to enhance the acquisition of language in general and vocabulary in particular. Here is the questionnaire:

1. How effective is the use subtitling in class?

( 0 - do not have an opinion, 1 -not at all, 2 - to some degree, 3 - quite effective, 4 - very effective)

2. Does subtitling enhance your language acquisition 
( 0 - not at all , 1 - a little , 2 - to some degree, 3 - yes, it does, 4- very much so)

3. How effective is it in your vocabulary acquisition

( 0 - not at all effective, 1 - a little effective, 2 - to some degree effective, 3 - quite effective, 4 - very effective)

4. Rate from 0 to 4 how beneficial is the subtitling type

(0- not beneficial, 1 - a little beneficial, 2 - quite beneficial, 3- beneficial , 4 - very beneficial)
a) Bimodal
b) Standard
c) Reversed

5. Rate from 0 to 4 the efficiency of the types of video clips

(0- not efficient at all, 1 - a little efficient, 2 - to a certain degree efficient, 3 - quite efficient, 4 - very efficient)
a) movies
b) documentaries
c) Manuals
d) Role play

Hereinafter are the results of the questionnaire of the academic year 2017/2018 —one hundred and fifty students filled in the form.

\begin{tabular}{|c|c|c|c|c|c|c|c|c|}
\hline$\#$ & \multicolumn{2}{|c|}{ Question } & 0 & 1 & 2 & 3 & 4 & $\begin{array}{l}\text { Mean } \\
\text { rating }\end{array}$ \\
\hline 1 & \multicolumn{2}{|c|}{$\begin{array}{l}\text { How effective is the use } \\
\text { subtitling in class? }\end{array}$} & $1 \%$ & $3 \%$ & $13 \%$ & $48 \%$ & $35 \%$ & 3.0 \\
\hline 2 & \multicolumn{2}{|c|}{$\begin{array}{l}\text { Does subtitling enhance } \\
\text { your language acquisition }\end{array}$} & $1 \%$ & $5 \%$ & $33 \%$ & $34 \%$ & $27 \%$ & 3.0 \\
\hline 3 & \multicolumn{2}{|c|}{$\begin{array}{l}\text { How effective is it in your } \\
\text { vocabulary acquisition }\end{array}$} & $1 \%$ & $4.1 \%$ & $32.7 \%$ & $30.6 \%$ & $31.6 \%$ & 3.0 \\
\hline \multirow[t]{3}{*}{4} & \multirow{3}{*}{$\begin{array}{l}\text { Rate the } \\
\text { importance } \\
\text { of the } \\
\text { subtitling } \\
\text { type you } \\
\text { used in } \\
\text { class }\end{array}$} & Bimodal & $2.7 \%$ & $1.3 \%$ & $26.7 \%$ & $57.3 \%$ & $12 \%$ & 3.1 \\
\hline & & Standard & $6.7 \%$ & $2.7 \%$ & $33.3 \%$ & $41.3 \%$ & $16 \%$ & 3.0 \\
\hline & & Reversed & $11 . \%$ & $32 \%$ & $36 \%$ & $10 \%$ & $11 \%$ & 2.1 \\
\hline \multirow[t]{4}{*}{5} & \multirow{4}{*}{$\begin{array}{l}\text { Rate the } \\
\text { type of } \\
\text { video clips }\end{array}$} & Movies & $3.5 \%$ & $7.1 \%$ & $23.5 \%$ & $34.1 \%$ & $31.8 \%$ & 2.7 \\
\hline & & Documentaries & $2.3 \%$ & $14.1 \%$ & $17.7 \%$ & $37.7 \%$ & $28.2 \%$ & 3.4 \\
\hline & & Manuals & $4.8 \%$ & $8.3 \%$ & $25 \%$ & $27.4 \%$ & $34.5 \%$ & 3.3 \\
\hline & & $\begin{array}{l}\text { Role play } \\
\text { dialogues }\end{array}$ & $14.9 \%$ & $30 \%$ & $21 \%$ & $32 \%$ & $13.1 \%$ & 3.0 \\
\hline
\end{tabular}

More than $65 \%$ of the subjects believe that using subtitling is positive and that it has been effective in the acquisition of language in general and vocabulary in particular. The questionnaire also shows that the great majority of students prefer 
bimodal and standard over reversed subtitling. As for the last question, it has proved that authentic video clips are more appreciated and enjoyed that artistic ones.

\section{Conclusion}

The aim of this paper was to provide a view on the tremendous effect that AVT in general, and subtitling in particular, can have on language learners. It is an attempt to gauge the learners' satisfaction with the active use of subtitles.

All in all, subtitling can be an important support for textbooks in vocabulary acquisition in ESP classes. Vocabulary teaching cannot be disassociated from its authentic setting. It should be taught through the medium of textbooks and enhanced through authentic techniques such as video watching and subtitling so as to be purposefully taught. Most ESP learners, in the case of our study, have enjoyed the pedagogical application of subtitling. They believe that it is both practical and enjoyable.

A future project which deserves study is the effect of smart subtitles. These are interactive subtitles tailored towards vocabulary learning. They provide features such as vocabulary definitions on hover and dialogue-based video navigation. The subtitles are simultaneously displayed in both L1 and L2 and word definitions are provided just by hovering on the word.

\section{References}

[1] Baltova, I. (1994). The impact of video on the comprehension skills of core Frenchstudents. The Canadian Modern Language Review 50, 507-532.

[2] Borrás, I and Robert, L. (1994). Effects of Multimedia Courseware Subtitling on the Speaking Performance of College Students of French. The Modern Language Journal 78(1), 61-75.

[3] Buil-Beltrán, P. (2018). Subtitling as a Teaching Tool for English for Specific Purposes'Students 4th International Conference on Higher Education Advances (HEAd'18) Universitat Politecnica de Valencia, Valencia,. DOI: http://dx.doi.org/10.4995/HEAd18.2018.8004

[4] Chaume, F. (2013). The turn of audiovisual translation: New audiences and new technologies. In Translation Spaces: Benjamin, 105-123

[5] Cummings, J. (2007), Rethinking Monolingual Instructional Strategies in Multilngual Classrooms. Canadiam Journal of Applied Linguistics, $X, 2,221-240$.

[6] Danan, M. (2010). Dubbing projects for the language learner: a framework for integrating audiovisual translation into task-based instruction. Computer Assisted Language Learning, XXIII, 5, 441-456.

[7] Díaz Cintas, J and Remael, A. ( 2007). Audiovisual Translation: Subtitling. Manchester:St Jerome.

[8] Díaz Cintas, J. (2010). The highs and lows of digital subtitles, in Lew N. Zybatow (ed) Translations wissens chaft - Stand und Perspektiven. Innsbrucker Ringvorlesungen zur Translationswissenschaft VI. Frankfurt am Main: Peter Lang, 105-130.

[9] Díaz Cintas, J. (2013). The Technology Turn in Subtitling. Translation and Meaning. Part 9, 119-132.

[10] Hatim, B and Mason, I. (1997). The Translator as Communicator, London: Routledge

[11] Herron, C, Hanley, J, and Coles, S. (1995). A comparison study of two advance organizers for introducing beginning foreign language students to video. The Modern Language Journal, 79(3), 387-395.

[12] Herron, C and Hanley, J. (1992). Using video to introduce children to foreign culture. Foreign Language Annals, 25(5), 419-427.

[13] Hurtado, A. (1999). Enseñar a traducir. Metodología en la formación de traductores eintérpretes. Madrid: Edelsa.

[14] Krashen, S. (1985). The Input Hypothesis: Issues and Implications.London and New York: Longman.

[15] Lertola, J. (2012). The effect of subtitling task on vocabulary learning, in Pym, Anthony. and Orrego-Carmona, David. (ed.), Translation research projects 4, Intercultural Studies Group, Tarragona, 61-70.

[16] Mayer, R. (2009). Multimedia learning. 2nd edition. Cambridge: Cambridge University Press.

[17] Sokoli, S. (2006). Learning via Subtitling: A tool for the creation of foreign language learning activities based on film subtitling. Audiovisual Translation Scenarios:Conference Proceedings, 1-8. Copenhagen: EU-High-Level Scientific Conference Series .

[18] Sokoli, S. et al (2011). Subtitling Activities for Foreign Language Learning: What Learners and Teachers Think in Incalcaterra McLoughlin et al. (ed.), Audiovisual Translation. Subtitles and Subtitling. Theory and Practice, Peter Lang, Bern, 219-242.

[19] Talaván, N. (2010). Claves para comprender la destreza de la comprensión oral en lengua extranjera, EPOS, XXVI, $198-216$.

[20] Talaván, N. (2011). A Quasi-experimental Research Project on Subtitling and Foreign Language Acquisition, in Incalcaterra McLoughlin, L. et al. (ed.), Audiovisual Translation. Subtitles and Subtitling. Theory and Practice, Peter Lang, Bern, 197-217.

[21] Talaván, N. and Rodríguez-Arancón, P. (2014). The use of reverse subtitling as an online collaborative language learning tool, in The Interpreter and Translator Trainer, VIII, 1, 84-101.

[22] Talaván, N. and Avila-Cabrera, J. (2014). First insights into the combination of dubbing and subtitling as L2 didactic tools, in Gambier, Yves. et al. (ed.) Subtitles and Language Learning, Peter Lang, Bern.

[23] Talaván, N, Rodríguez-Arancón, P and Martín-Monje, E. (2015). The enhancement of speaking skills practice and assessment in an online environment. In Cancelas y Ouviña and Sánchez Rodriguez (ed.), Tendencias en educación y lingüística, Editorial GEU, 329-351

[24] Widdowson, H. (2003). Defining issues in English language teaching. Oxford: Oxford University Press. 